\title{
The Concept Of "People's Diplomacy", Its Content And Significance
}

\begin{abstract}
Kholmatov Bakhodir Kholmuradovich, Senior Lecturer, Department Of "Socio-Political Sciences", Tashkent Institute Of Chemical Technology, Uzbekistan
\end{abstract}

\author{
Akhmadjonova Gulnoza Rustamjon Kizi, \\ Independent Researcher, International Islamic \\ Academy Of Uzbekistan
}

\author{
G OPEN ACCESS \\ The American Journal of \\ Social Science And \\ Education Innovations \\ JULY 2020 \\ Page No.: 177-183 \\ Volume-II Issue-VII \\ PUBLISHED: 30 JULY 2020 \\ www.usajournalshub.com/inde \\ x.php/tajssei \\ Copyright: Original content \\ from this work may be used \\ under the terms of the \\ Creative Commons Attribution \\ 4.0 licence.
}

\section{Abstract}

The article describes the essence of the concept of "people's diplomacy", the definitions of the concept by foreign and domestic scholars, the analysis of approaches and its differences from state diplomacy. The role of "people's diplomacy" in maintaining peace in the world, developing interstate relations and establishing friendly relations between different peoples was also discussed.

Keywords: "People's diplomacy", "diplomacy", "globalization", "integration", foreign policy, "soft power", national interests, cultural relations, non-governmental organizations (NGOs), the Center for People's Diplomacy.

\section{Introduction}

In today's world, where globalization and integration processes are intensifying, "people's diplomacy", which is recognized as one of the important aspects of modern diplomacy, is becoming the most basic and integral part of international relations.

The concept of "people's diplomacy" is a new reality in international relations, but it is gaining a strong foothold in today's modern world as a very important, influential factor uniting different states and peoples. Therefore, "people's diplomacy" has many positive and influential features, in contrast to state diplomacy.

At this point, let's explain the previous concepts of "globalization" and "integration".

One of the well-known scientists of our country, Professor S. Otamuratov, said that "globalization is an objective law of human development and reflects its continuity. 
Therefore, globalization is a process and humanity is not able to stop it or put obstacles in its way" [1, Otamuratov S., 2013.p.14], - he notes.

Integration is the gradual formation of an international system aimed at addressing global and regional issues in the political, economic, legal and socio-cultural spheres, aimed at ensuring the national interests of states, international peace, stability, security and cooperation, mutual trust and goodwill among the public [2 , Kucharov Ch.Sh., 2008.p.44-45].

\section{The Main Findings And Results}

So what is meant by "people's diplomacy"?

At the same time, we can see that in many cases the concept of "people's diplomacy" is interpreted in many sources as a form of socio-political, cultural relations of public associations that are not part of the government.

The term "people's diplomacy" was first coined in 1965 by Edmund Gullion, a former American diplomat and dean of the Fletcher School of Law and Diplomacy at Taft University (USA). This concept is still widely used by scientists and practitioners around the world.

Theorist E. Gullion defines this term "people's diplomacy" as follows: "People's diplomacy deals with the influence of public opinion on the formation and conduct of foreign policy. It covers relations in international relations that go beyond traditional diplomacy, the formation of public opinion by the government in the country, the interdependence of private groups and interests, on the other hand, reporting on international affairs and their impact on politics, relations between diplomats and foreign correspondents, and intercultural relations learns the process of communication" [3, www.uscpublicdiplomacy.org].

If we pay attention to the opinion of E. Gullion, we will see that he defined the concept of "people's diplomacy" on a large scale, and his ideas reflect its relevance today. This is because he argued that public opinion should be taken into account in the formulation and conduct of the foreign policy of the state. He also acknowledged that "people's diplomacy" encompasses international relations that go beyond traditional diplomacy.

It is known that in traditional diplomacy, states mainly establish diplomatic relations based on certain requirements, prioritizing economic and political interests in entering into relations with each other.

According to J.S. Nay, a well-known American political scientist and author of the term "soft power", a professor at Harvard University, "people's diplomacy is an important tool of the" smart power "method, but it is important in creating" soft power"; it requires 
trust, self-criticism and an understanding of the role of civil society "[4, www.dash.harvard.edu].

For information: "soft power" is the ability of a state to engage with its own culture, socio-political values. It also refers to the state's ability to influence international relations and other countries through its own policies, culture, brands, education system, image, and other similar factors [5, Nye ]., 1990.№.80].

In our view, the scientist believes that "soft power" does not achieve what he wants by coercion and payment, as "hard power" (economic and military power), but by gaining and attracting supporters without using military or economic resources.

According to the Russian scientist N.A. Akhundov, "people's diplomacy" is a broad, mass movement of various social forces that has a significant impact on the solution of pressing problems of the modern world community [6, Akhundov N.A., 1991.p.40].

Also, another Russian researcher, T.I. Medvedeva describes the concept of "people's diplomacy" as follows. According to him, "people's diplomacy" is the informal foreign policy of individuals and legal entities independent of governments, non-governmental organizations (NGOs), actions and institutions aimed at maintaining peace, developing and improving interstate relations, friendship, mutual understanding, cooperation between different peoples and domestic political activity "[7, Medvedeva T.I., 2007.p.17].

Here we can see that the concept of "people's diplomacy" has a much broader approach than the definition of the above-mentioned Russian scientist NA Akhundov.

The reason is that the researcher TI Medvedeva said that the concept is based on such goals as maintaining peace in the world, developing and improving interstate relations, as well as the establishment of friendly relations between different peoples.

Kazakh researchers L.J. Abjaparova and A.B. Sarsembaeva noted that in the "new world order" "people's diplomacy" has become one of the main participants in international relations, "people's diplomacy" public organizations and associations, relations at the level of sister cities; socio-political movements, international nongovernmental organizations [8, www.fundamental-research.ru].

It can be seen that the activities of public organizations and associations, the initiatives of international non-governmental organizations to strengthen cooperation allow to develop relations between the countries at all levels.

If we pay attention to the opinion of the Tajik researcher B.H. Bakhriev, he describes "people's diplomacy" as "... actions aimed at establishing long-term relationships, defending national foreign policy goals, and better understanding the values and institutions of one's own country abroad" [9, Bakhriev BH, 2017.p.131].

This shows that the researcher $\mathrm{BH}$ Bakhriev, in contrast to others, saw the concept as an effort to protect the goals of national foreign policy, to better understand the values 
of their country abroad.

According to the Uzbek researcher RT Juraev, "People's diplomacy is a legitimate necessity of generality and individuality, a common international relationship that includes all forms of relations, social, economic, political, cultural dialogue and all segments of the population - workers, peasants, intellectuals, religious and party leaders, students, schoolchildren" [10, Juraev R.T., 1999. p.24].

It can be understood from this that the researcher R.T. Juraev defined the concept of "people's diplomacy" only in the context of the state's domestic policy.

According to a well-known diplomat, Senator S.S. Safaev, "people's diplomacy is" diplomacy from heart to heart, "which helps bring peoples and society closer together. These are the ties that bring people together, and it is through people's diplomacy that people begin to understand each other better "[11, www.sputniknews-uz.com]," he said.

It is self-evident that in the development of this form of diplomacy, first of all, the "human factor" plays a leading role. In doing so, the behavior of a particular individual or group contributes to the rapprochement of peoples and communities. At the same time, it has a positive effect on the mutual understanding of the parties.

Professor A. Fayzullaev called "people's diplomacy" "an important part of foreign policy aimed at explaining the goals and values of the state to the general public, creating a positive image of the country and promoting its interests in the international arena, improving relations between peoples" [12, www.gazeta.uz ], - he evaluates.

From this definition of the author it is clear that "people's diplomacy" is an important part of the foreign policy of the state in creating a positive image of the country, as well as improving relations between peoples.

Based on the above, "people's diplomacy", in contrast to state diplomacy, is the establishment of interstate and interregional cooperation through the extensive use of various cultural tools and the age-old values of peoples; it can also be said to be the skill of making efforts to improve relations between peoples and nations.

Today, Uzbekistan's well-thought-out policy of ensuring national and religious tolerance, strengthening the atmosphere of mutual respect in society - and thus preserving social stability, peace and tranquility - is highly recognized in our region and internationally.

Consequently, mutual trust and good neighborly relations between countries and peoples pave the way for cooperation in the political, economic, social, as well as cultural and humanitarian spheres in the world. "People's diplomacy" plays a leading role in achieving such goals.

At the same time, the priorities of further expanding cultural and humanitarian cooperation between the Central Asian countries, strengthening the role of the institute of 
"people's diplomacy" in strengthening ties, strengthening friendship and partnership between Uzbekistan and Central Asian countries in accordance with the Action Strategy [13, www.lex.uz] the growing role of national cultural centers and friendship societies in 'people's diplomacy' can be seen.

In this regard, the President of the Republic of Uzbekistan Shavkat Mirziyoev noted that the mutually beneficial relations with the Central Asian states have reached a new stage, ".. we support the continuation of active cultural and humanitarian dialogue, the regular organization of cultural days and various creative events in our countries, the development of exchanges in the field of education and tourism as the most important tool of "people's diplomacy" [14, www.prezident.uz].

In addition, the expansion of relations at the level of neighboring countries, the active use of "people's diplomacy" mechanisms also enrich the relations between the countries of the region.

At the same time, it should be noted that the President of the Republic of Uzbekistan Shavkat Mirziyoev put forward the idea of establishing a permanent SCO "People's Diplomacy Center" at the SCO Summit in Astana, Kazakhstan on June 8-9, 2017 [15, www. President.uz].

Then, in accordance with the Resolution of the President of the Republic of Uzbekistan dated June 26, 2018 "On measures to support the establishment of the People's Diplomacy Center of the Shanghai Cooperation Organization in Uzbekistan" [16, www.lex.uz], the Center for Public Diplomacy of the Shanghai Cooperation Organization in Uzbekistan established.

For information: On August 7, 2018, the Ministry of Justice of the Republic of Uzbekistan (as an institution in the form of a non-governmental non-profit organization) registered the Center for Public Diplomacy of the Shanghai Cooperation Organization in Uzbekistan.

The main goal of the center is to contribute to the strengthening of mutual trust and good neighborliness, interethnic and interreligious harmony, and dialogue between civilizations between the SCO member states.

The Center also includes the implementation of cultural, scientific, educational programs, the organization of delegation visits, art exhibitions, music festivals, art festivals, the development of international relations and cooperation.

At present, "people's diplomacy" is carried out in the framework of the activities of national cultural centers and societies aimed at friendship and mutual understanding between peoples. The efforts of these public associations in the framework of "people's diplomacy" serve to establish good neighborly relations between the peoples of the countries. 
To conclude, the institute of "people's diplomacy" has a special role as a positive factor in promoting national interests and strengthening international relations. The activities of public associations aimed at strengthening the cooperation of countries and peoples and the initiatives of international non-governmental organizations will undoubtedly contribute to the further unification of peoples, taking into account national interests.

After all, "people's diplomacy" - in contrast to state diplomacy, which has many positive and influential features, is free from official statements, "people's diplomacy" can be highly valued as an important institution of international relations in recent years.

\section{References}

[1] Otamuratov S. (2013) Globalization is a national-spiritual security. (Political and philosophical analysis) - Tashkent. "Uzbekistan". - p. 14.

[2] Kucharov Ch.Sh. (2008) Problems of the Central Asian regional integration process. A dissertation for the degree of Doctor of Political Science. - Toshkent. - pp. 44-45.

[3] «Public diplomacy» before Gullion: the evolution of a phrase. Apr 18, 2006. https://www.uscpublicdiplomacy.org/blog/public-diplomacy-gullion-evolution-phrase

[4] Nye J.S. "Public Diplomacy and Soft Power" The ANNALS of the American Academy of Political and Social Science 616 (1) (March 1): $2008.94-109$. https://dash.harvard.edu/handle/1/11738397

[5] Nye J., Jr. Soft power / Nye J., Jr. // Foreign Policy. - Washington. - 1990. - № 80.

[6] Akhundov N.A. (1991) Public diplomacy in modern world politics (second half of the $80 \mathrm{~s}$ - 90s). Abstract of dissertation for the degree of Doctor of Historical Sciences. Moscow. - p. 40.

[7] Medvedeva T.I. (2007) Civil (people's) diplomacy and its role in the Russian-Japanese political dialogue. Abstract of dissertation for the degree of candidate of political sciences. - Moscow. - p. 17.

[8] Abzhaparova L. J., Sarsembaeva A.B. Public diplomacy as a factor in international relations: the historical experience of Kazakhstan. https://www.fundamentalresearch.ru/ru/article/view?id $=33376$

[9] Bakhriev B.Kh. Public diplomacy in modern research discourse // Bulletin of the Tajik State University of Law, Business and Politics. Social Science Series. - 2017. - No. 1 (70). - p. 131.

[10] Joraev R.T. The role of people's diplomacy in Uzbekistan in international relations. Dissertation for the degree of Candidate of Historical Sciences. - Tashkent. - p. 24. 
[11] Safaev: People's diplomacy helps to succeed in all areas. https://sputniknewsuz.com/politics/20190129/10661499/

[12] Fayzullaev A. Public diplomacy on the service of national interests. https://www.gazeta.uz/ru/2017/08/05/public-diplomacy/

[13] Decree of the President of the Republic of Uzbekistan "On the Strategy for further development of the Republic of Uzbekistan". February 7, 2017, No. PF-4947. https://lex.uz/docs/3107036

[14] Speech by President of the Republic of Uzbekistan Shavkat Mirziyoev at the International Conference "Central Asia: Common History and Common Future, Cooperation for Sustainable Development and Progress" in Samarkand. http://www.prezident.uz/uz/lists/view/1227.

[15] SCO Summit in Astana. https://president.uz/uz/lists/view/631

[16] Resolution of the President of the Republic of Uzbekistan "On measures of state support for the establishment of the Center for Public Diplomacy of the Shanghai Cooperation Organization in Uzbekistan." June 26, 2018, No. PQ-3807. https://lex.uz/docs/3795314 